\title{
A chronic eosinophilic leukemia patient presenting with blurred vision
}

\section{Bulanık görmeyle başuuran kronik eozinofilik lösemi hastası}

\author{
Demircan Özbalcı1, Ülkü Ergene1, Harun Yazgan² \\ 'Department of Hematology, Faculty of Medicine, Celal Bayar University, Manisa, Turkey \\ ${ }^{2}$ Department of Internal Medicine, Faculty of Medicine, Celal Bayar University, Manisa, Turkey
}

Chronic eosinophilic leukemia (CEL), a rare entity, is classified by the $\mathrm{WHO}$ as 2 groups of patients with neoplastic eosinophils: those that have a myeloid or lymphoid neoplasm with eosinophilia, and abnormalities in PDGFRA, PDGFRB, or FGFR1 genes, and those integrated in a subchapter as MPN that have chronic eosinophilic leukemia, not otherwise specified [1-3]. Hepatosplenomegaly, eosinophilia with systemic disturbances, anemia, thrombocytopenia, and in particular cardiac involvement are major components of the disease [4].

A 32-year-old male that had previously been healthy presented to our clinic with fatigue, blurred vision, non-productive cough, and sore throat that began $10 \mathrm{~d}$ earlier. Physical examination showed splenomegaly $10 \mathrm{~cm}$ below the costal margin, and segmentation and dilatation of capillaries around the optic disc. His hemogram results were as follows: Hg: $9.2 \mathrm{~g} / \mathrm{dL}$, WBC: 50,000/ $\mathrm{LL}$; Plt count: 98,000/ $\mathrm{L}$; eosinophils: $21,100 / \mu \mathrm{L}$. Peripheral blood smear showed $62 \%$ eosinophils. Bone marrow aspiration showed $<50 \%$ myeloid cells that were eosinophils and $\leq 3 \%$ blasts.

Fluorescent in situ hybridization analysis of $\mathrm{t}(9 ; 22)$ was negative. Tests for BCR-ABL and FIP1L1-
PDGFRA rearrangement with real time PCR were performed. Parasite tests for eosinophilia were negative. Hypotensive attacks with dynamic electrocardiographic changes were observed and methylprednisolone $1 \mathrm{mg} / \mathrm{kg} / \mathrm{d}$ was initiated following observation of pericardial effusion. The effusion resolved, but despite steroid therapy his eosinophil count did not change as expected, and red blood cell and thrombocyte transfusions were required during follow-up. BCR-ABL rearrangement was negative and FIPL1-PDGFRA rearrangement of RNA was observed; therefore, imatinib $100 \mathrm{mg} / \mathrm{d}$ was initiated and steroid therapy was immediately withdrawn. His clinical condition quickly improved, eosinophilia disappeared, vision improved, and he was transfusion free. The patient was discharged in good health and during his last outpatient follow-up his $\mathrm{Hg}$ was $12.3 \mathrm{~g} / \mathrm{dL}, \mathrm{WBC}$ was $5600 / \mu \mathrm{L}$, Plt count was $148,000 / \mu \mathrm{L}$, and eosinophils was $0.4 \%$.

CEL, once a disease with a poor prognosis, is now a manageable disease associated with a good quality of life using tyrosine kinase inhibitors. The FIP1L1-PDGFRA fusion gene was reported to be 50 -fold more sensitive to the tyrosine kinase inhibitor imatinib [5] than BCR-ABL, and as such low- 
dose $(100 \mathrm{mg} / \mathrm{d})$ imatinib rapidly achieves hematologic and molecular response. The presented case was transfusion-dependent and had vision loss attributed to eosinophilia; however, following initiation of imatinib therapy his clinical and hematologic condition quickly improved.

We had obtained written informed consent from the patient.

\section{Conflict of interest statement}

The authors of this paper have no conflicts of interest, including specific financial interests, relationships, and/or affiliations relevant to the subject matter or materials included.

\section{References}

1. Valent P. Pathogenesis, classification and therapy of eosinophilia and eosinophil disorders. Blood Reviews 2009;23:157-65.

2. Bain B, Gilliland DG, Vardiman JW, Horny HP. Chronic eosinophilic leukaemia, not otherwise specified. In:
Swerdlow SH, Campo E, Harris NL, Jaffe ES, Pileri SA, Stein $\mathrm{H}$, Thiele J, Vardiman JW, editors. WHO classification of tumours of haematopoietic and lymphoid tissues, vol. 2. Geneva (Switzerland) and Albany (NY, USA): WHO Press; 2008;51-3.

3. Bain B, Gilliland DG, Horny HP, Vardiman JW. Myeloid and lymphoid neoplasms with eosinophilia and abnormalities of PDGFRA, PDGFRB, orFGFR1. In: Swerdlow SH, Campo E, Harris NL, Jaffe ES, Pileri SA, Stein H, Thiele J, Vardiman JW, editors. WHO classification of tumours of haematopoietic and lymphoid tissues, vol. 2. Geneva (Switzerland) and Albany (NY, USA): WHO Press; 2008;68-73.

4. Sheikh J, Weller FW. Advances in diagnosis and treatment of eosinophilia. Current Opinion in Hematology 2009;16:3-8.

5. Cools J, DeAngelo DJ, Gotlib J, Stover EH, Legare RD, Cortes J, Kutok J, Clark J, Galinsky I, Griffin JD, Cross NC, Tefferi A, Malone J, Alam R, Schrier SL, Schmid J, Rose M, Vandenberghe P, Verhoef G, Boogaerts M, Wlodarska I, Kantarjian H, Marynen P, Coutre SE, Stone $\mathrm{R}$, Gilliland DG. A tyrosine kinase created by fusion of the PDGFRA and FIP1L1 genes as a therapeutic target of imatinib in idiopathic hypereosinophilic syndrome. N Engl J Med 2003;348:1201-14. 